\title{
Does the UK need a Human Taphonomy Facility?
}

\begin{abstract}
Human Taphonomy Facilities (HTFs) are outdoor laboratories where scientific research is carried out on donated human cadavers in order to understand how human decomposition progresses in a variety of conditions. There are currently eight such facilities in the USA, one in Australia and one on mainland Europe. Forensic scientists in the UK have started to ask the question 'Does the UK need a Human Taphonomy Facility?'. A review of the literature produced by the existing HTFs, as well as published opinion and commentaries about these facilities and the feasibility of one in the UK has been undertaken. The existing arguments for and against the establishment of a Human Taphonomy Facility in the UK have been examined. Given recent media interest in the possibility of the establishment of a Human Taphonomy Facility in the UK, and the surrounding controversy, it is important to evaluate the potential benefit or harm of the creation of such a facility to Society and the scientific community.
\end{abstract}

Keywords: Human Taphonomy Facility; 'Body Farm'; taphonomy; decomposition; forensic anthropology; human cadavers

\section{Introduction}

Human Taphonomy Facilities (HTFs) are outdoor laboratories where scientific research is carried out on donated human cadavers in order to understand how human decomposition progresses in a variety of conditions (Gill, 2017). Colloquially, these facilities have become known as 'body farms', as a result of the Patricia Cornwell (Cornwell, 1994) novel of the same name, which captured the public imagination, and media perpetuation of the term. The use of this term is avoided by forensic scientists, as it is not an accurate or dignified way to describe the scientific research undertaken at such facilities (Forbes, 2017).

Research conducted at the existing HTFs, and in particular at the oldest one, based at the University of Tennessee, Knoxville (UTK), has contributed to our knowledge of human decomposition, through scientific monitoring and documentation of the post-mortem changes occurring in human bodies under controlled conditions (Gill, 2017). It has highlighted the enormous amount of variability that exists between and among humans, and that the rate of decomposition is affected by a vast array of factors, including temperature, humidity, access by insects, cause of death, clothing, body size and fat content, local fauna, soil type and many more (Blau, 2017; Byard, 2017). Research at UTK and other HTFs has also demonstrated that the data generated is only applicable to the immediate environment, particularly for postmortem interval estimation (Forbes, 2017; Connor et al., 2017). As a result, there is an ongoing need to establish HTFs in other geographical and climatic regions across the world. Currently, there are eight operational Human Taphonomy Facilities (HTFs) in the USA, one 
in Australia and one in The Netherlands, and there are plans to create another in Australia (Forbes, 2017; Stuzner, 2016), Canada, and more in continental Europe (Enserink, 2017) (Table 1).

\begin{tabular}{|c|c|c|c|}
\hline $\begin{array}{l}\text { Name of } \\
\text { Human Taphonomy Facility }\end{array}$ & $\begin{array}{l}\text { Institutional } \\
\text { affiliation }\end{array}$ & Location & $\begin{array}{l}\text { Date } \\
\text { established }\end{array}$ \\
\hline Forensic Anthropology Center & $\begin{array}{l}\text { University of Tennessee, } \\
\text { Knoxville }\end{array}$ & $\begin{array}{l}\text { Knoxville, TN, } \\
\text { USA }\end{array}$ & 1981 \\
\hline $\begin{array}{l}\text { Forensic Osteology Research Station } \\
\text { (FOREST) }\end{array}$ & $\begin{array}{l}\text { Western } \\
\text { University }\end{array}$ & $\begin{array}{l}\text { Cullowhee, NC, } \\
\text { USA }\end{array}$ & 2005 \\
\hline $\begin{array}{l}\text { Forensic Anthropology Research } \\
\text { Facility (FARF) }\end{array}$ & Texas State University & $\begin{array}{l}\text { San Marcos, } \\
\text { TX, USA }\end{array}$ & 2008 \\
\hline $\begin{array}{l}\text { Applied Anthropological Research } \\
\text { Center }\end{array}$ & $\begin{array}{l}\text { Sam Houston } \\
\text { University }\end{array}$ & $\begin{array}{l}\text { Huntsville, TX, } \\
\text { USA }\end{array}$ & 2010 \\
\hline $\begin{array}{l}\text { Complex for Forensic Anthropology } \\
\text { Research (CFAR) }\end{array}$ & Southern Illinois University & $\begin{array}{l}\text { Carbondale, IL, } \\
\text { USA }\end{array}$ & 2012 \\
\hline $\begin{array}{l}\text { Forensic Investigation Research } \\
\text { Station (FIRS) }\end{array}$ & Colorado Mesa University & $\begin{array}{l}\text { Grand Junction, } \\
\text { CO, USA }\end{array}$ & 2013 \\
\hline $\begin{array}{l}\text { Australian Facility for Taphonomic } \\
\text { Experimental Research (AFTER) }\end{array}$ & $\begin{array}{l}\text { University Technology, } \\
\text { Sydney }\end{array}$ & $\begin{array}{l}\text { Yarramundi, } \\
\text { New South } \\
\text { Wales, Australia }\end{array}$ & 2016 \\
\hline $\begin{array}{l}\text { Florida Forensic } \\
\text { Research, Security } \\
\text { Rrainitute for } \\
\text { Traing (FIRST) }\end{array}$ & University of South Florida & $\begin{array}{l}\text { Tampa, } \\
\text { USA }\end{array}$ & 2017 \\
\hline ARISTA & Academic Medical Center & $\begin{array}{l}\text { Amsterdam, The } \\
\text { Netherlands }\end{array}$ & 2018 \\
\hline $\begin{array}{l}\text { Forensic Research Outdoor Station } \\
\text { (FROST) }\end{array}$ & $\begin{array}{l}\text { Northern } \\
\text { University }\end{array}$ & $\begin{array}{l}\text { Marquette, MI, } \\
\text { USA }\end{array}$ & In progress \\
\hline
\end{tabular}

Table 1 List of existing HTFs around the world (Schubert, 2018).

\section{Use of animal analogues}

Currently in the UK, in the absence of a Human Taphonomy Facility, forensic scientists have to use animal analogues to carry out scientifically rigorous decomposition research. There are several animal-based taphonomy facilities at universities around the country, where animal carcasses ${ }^{1}$, usually pigs (Sus scrofa), but occasionally sheep (Ovis aries), deer (Cervus sp.) or rabbits (Oryctolagus caniculus)) are used as proxies for humans, and monitored in a variety of UK geographical and climatic conditions. The porcine model has undoubtedly contributed

\footnotetext{
${ }^{1}$ The animals are not killed for the purposes of the research.
} 
greatly to our understanding of the nature of forensic science in all its facets (Bachmann and Simmons, 2010; Schultz et al., 2006; Schultz, 2008; Pringle et al., 2012; 2016; Lynch-Aird et al., 2015).

Some forensic taphonomy researchers claim that the use of animal analogues for empirical research offers an advantage over the use of human cadavers. These advantages are mainly associated with the commonality between individuals and the possibility of replicates. Animal carcasses can be routinely and cheaply acquired for multiple replicate studies (Troutman et al. 2014) to ensure results are statistically valid. The acquired animal carcasses also have typically common origin, diets, exercise, weights, ages and manner of death. This therefore makes it easier, when, for example, looking at decomposition rates, that these listed variables can largely be factored out, whereas a HTF will be dependent on donor human cadavers, who will be of variable origin, diet, exercise, weight, and manner of death. Therefore, comparing the results between donated human remains in large-scale studies is more difficult than when comparing results using animal proxies (Williams et al., 2018). However, recent research at HTFs, where humans and animals cadavers have been placed to decompose simultaneously, has shown that that pigs decompose differently to humans. A study conducted at the Forensic Anthropology Center at UTK examined how pigs, rabbits, and humans decomposed in the same environment (Alapo, 2016). All of the test animals decomposed at different rates, with pig cadavers decomposing faster than humans on average; and there was more inter-individual variation in the humans than between the rabbits or pigs. A 2012 study in Texas also found differences in scavenging between animal and donated human cadavers (Rippley et al., 2016; Knobel et al., 2018). These differences suggest that animal carcasses not suitable as analogues for human remains (Duatartas et al., 2018; Connor et al., 2017; Stokes et al., 2013; Knobel et al., 2018; Alapo, 2016).

\section{Research at Human Taphonomy Facilities}

\section{Human conditions}

Human Taphonomy Facilities offer the chance to study, under as controlled environments as possible, the effect of certain human conditions and lifestyle choices on decomposition rate and subsequent post-mortem interval estimation; something that is simply not possible to do with animal analogues (Madea and Doberentz, 2017). Recent research (Buffington, 2016) has shown that certain conditions such as autism affect the populations of bacteria in the gut. As gut bacteria have been described as driving the process of decomposition (Hyde et al., 2013; Janaway et al., 2009; Pechal et al., 2013; Vass, 2001), it stands to reason that any condition that affects the abundance and populations of gut bacteria will also affect decomposition rate. Diseases such as cancer and diabetes (Zhou and Byard, 2011; Smialek and Levine, 1998), and lifestyle variation such as smoking, medication, drug use, or diet are likely to affect decomposition rates, but it is impossible to scientifically investigate this effect without the use of donated human cadavers, and subjecting animals to these factors would be ethically and morally unacceptable. Current methods for estimation of post-mortem interval often fail to take these variables into account, and so estimations can be inaccurate and unreliable. Animal studies are still necessary, especially given the scarcity of HTFs around the globe; but humans are the preferred subject for forensic taphonomy empirical research (Forbes, 2017). 
Current research being undertaken at existing HTFs focusses on more than improving the estimation of post-mortem interval. It is also geared towards search and location of missing individuals or clandestine depositions; identification of deceased individuals; training of human remains detection dogs; persistence of trace evidence (e.g.: pollen, gunshot residue, diatoms, paint or fibres) in association with decomposing remains. Further research being undertaken at HTFs include comparing decomposition rates between animals and humans; investigating the survivability of fingerprints at different stages of decomposition; studying heat generation by insect activity; investigating the decomposition of frozen remains, to name a few (Blau, 2017). The scope of this research necessarily includes many sciences related to forensic science, such as geology and geophysics, archaeology, environmental science, ecology, botany, pathology and medicine, and analytical chemistry, for example. Current research at AFTER is monitoring how facial tissue thicknesses change with post-mortem interval (Stuzner, 2016), as well as volatile organic compound release from cadavers (Luong et al., 2018; Knobel et al., 2018). In addition, research has also started on the detection of clandestine and mass graves through the use of LiDAR scanning, hyperspectral imagery, infra-red photography and drone imaging (Blau, 2017).

Some forensic scientists are sceptical about the value of the research published by existing HTFs around the world, citing low sample sizes for experiments and a lack of rigorous scientific technique (Black, 2017). While porcine experiments provide reproducibility in terms of similar body mass, diet or genetics, no amount of repeatability will account for the differences observed when compared to human decomposition (Forbes, 2017). Also, researchers such as Byard (2017) have suggested that microclimates present within HTFs may render the data produced non-transferrable to other cases. Instead, this emphasises the need for HTFs to repeat studies as frequently as possible, and establish longitudinal data sets that can be used to estimate average rates or patterns in rates of decomposition (Forbes, 2017; Oostra, 2018).

\section{Practitioner and student training}

The benefits of HTFs for the forensic community extend beyond research applicable to casework. HTFs also offer the opportunity for training police, military and law enforcement personnel, as well as university students, in the excavation and recovery of human remains. Training is undertaken at UTK in collaboration with the FBI. Such training encourages collaboration between scientists and police to ensure research undertaken focusses on reallife problems (Forbes, 2017). The pedagogical value of such facilities is immense (Blau, 2017; Cross and Williams, 2017). Such facilities offer students valuable opportunities to gain hands-on experience of the sights and smells associated with the decomposing human remains. The fact that short courses in human remains excavation and recovery offered by existing HTFs, such as University of Tennessee Knoxville, are consistently over-subscribed demonstrates that university students and law enforcement personnel prize the experiences that can only be gained at these unique facilities (www.fac.utk.edu). In the UK, without easy access to HTFs, the majority of UK Forensic Science graduates enter careers as forensic scientists or crime scene investigators without ever being exposed to the sensory experience of decomposing human remains, and therefore without knowing if they are suited for the role. 
To combat this, many UK universities arrange regular field trips to existing HTFs in order to offer this opportunity to their students (www.keele.ac.uk).

In addition, at some HTFs, human remains are retained after decomposition (with donor consent) to become part of osteological teaching collections. These collections, such as the WM Bass Donated Skeletal Collection at UTK, are of clear benefit to students of osteology, as they contain known individuals with demographic data, and allow students to study modern diseases and conditions manifest in the skeleton, as well as modern medical interventions and cultural modifications, as well as modern population variation (https://fac.utk.edu/wm-bass-donated-skeletal-collection/). Since the UTK collection was started in 1994, over 130 researchers from universities and law enforcement agencies such as the FBI have visited the collection, and researchers have documented differences between the individuals in the collection, with late $20^{\text {th }}$ century and early $21^{\text {st }}$ century death dates and those from archaeological collections with death dates from the early $20^{\text {th }}$ century or earlier, including stature increases and changes in cranial morphology (Shirley et al., 2011). The documentation of this modern variation has demonstrated the importance of using modern skeletal specimens to establish anthropological criteria for the estimation of sex, age, ancestry and stature from skeletal remains (Shirley et al., 2011). This is obviously impossible with most archaeological skeletal collections, or even those such as the Hamman-Todd skeletal collection. With the increasing use of digital technology, it is possible that human skeletal remains at HTFs could be 3D scanned and printed, which would mean that the remains would not have to be kept indefinitely as part of the osteological collection, but could be returned to families for burial or cremation after the decomposition research is finished. Online databases of measurements, scans and 3D printed material could be used for teaching and shared between researchers, allowing research using modern skeletal data without damaging potentially fragile human remains (Kuzminsky and Gardiner, 2012). In the UK, studies of modern skeletal variation are limited by access to modern skeletal collections, especially in comparison with the USA and Japan (Mays, 2010), and so the access to modern skeletal populations that a UK HTF would provide would be of tremendous value to the forensic and biological anthropology in the UK. As Blau states in 2017, "the opportunity to undertake research on skeletal remains with known demographic and health information is invaluable for the development of forensic anthropology".

\section{Human remains detection dog training}

Another valuable benefit of HTFs is the opportunity to undertake training, licensing and competency testing of human remains detection (HRD) dogs. The newly opened HTF in Pasco County, Florida, has recognised the potential for the improvement of the training of such dogs (Steele, 2017). In the USA, operational HRD dogs are required to undertake regular competency testing, which tests their ability to find human remains in a variety of settings, and to ignore animal carcasses (Cablk et al., 2012).

In countries lacking HTFs, HRD dogs are trained using human bodily fluids (blood, semen, or decomposition fluid) or substances that have been found in association with human remains (for example clothes or carpet). Occasionally, extracted human teeth may be used (Irish, 2018). Otherwise, HRD dogs are trained using animal analogues for humans, usually porcine carcasses (Knobel et al., 2018), and yet are expected to consistently find human 
remains operationally (Irish, 2018). Recently, comparative analyses of VOCs produced during human and pig decomposition have been conducted at AFTER (Stadler et al., 2013; Stokes et al., 2013) that show that there are differences between them in terms of ratio and abundance of VOCs, resulting in differing odour profiles (Cablk et al., 2012). Whist these results need further verification, they suggest that UK HRD dogs are not being trained in the most effective way. HTFs would allow the training of HRD dogs on human remains in a variety of scenarios in a controlled, secured setting, and would allow 'blind' or 'double-blind' testing, where neither handler nor dog knows where the remains are, or indeed if remains are present - something which is rarely carried out in training regimes currently (Cablk et al., 2012; Irish, 2018).

\section{Expert witness testimony}

In 2018, the Forensic Science Regulator published a document detailing legal obligations in the context of the expert witness working in the Criminal Justice System of England and Wales. Within its discussion of the admissibility of expert testimony, it details that evidence is only admissible if it is relevant and reliable. In the context of any UK based taphonomic research, we cannot be certain of the reliability of using animal models to develop data, or answer questions relating to human decomposition (duration, deviations in the process, scavenging of remains, differential patterns of decomposition, etc.). Furthermore, the Crown Prosecution Service's Legal Guidance document (2015) states that expert witnesses should only testify in relation to matters within their knowledge and have relevant experience - at present there are very few people in the UK who have sufficient knowledge and experience in how a human body decomposes. Extrapolation of data collected from animal studies opens the possibility of criticism from the opposing counsel in court. As Wallman (2017) states, "by providing access to actual dead bodies rather than non-human proxies, body farms can play an invaluable role in upholding evidentiary standards in this discipline [forensic entomology] and help avoid unreliable assumptions".

Likewise, as Black (2017) has said, the President's Advisory Council (2016) have questioned the validity of all forensic science, which means that forensic science has to prove its merit through scientifically robust empirical research. When it comes to understanding and interpreting human decomposition, that empirical research cannot be done on animal analogues. The potential boost to the public and court confidence in the expert witness testimony of forensic scientists using human data in their analyses undoubtedly outweighs the cost to an institution to establish a Human Taphonomy Facility.

\section{Ethical considerations}

Human Taphonomy Facilities, like medical and anatomy schools, depend on the generous donation of cadavers from members of the public. In the early years after the opening of the facility at University of Tennessee, Knoxville, many of the donations were unclaimed bodies from the State of Tennessee Medical Examiner, but little was known about these individuals (Shirley et al., 2011). Now, the Forensic Anthropology Center, as other HTFs, have long lists of pre-donors awaiting donation. 
Some academics in the UK are concerned that the existence of a UK HTF will upset the delicate balance that currently exists between the public and anatomy and medical schools. They suggest that the presence of a HTF may taint the reputation or perception of donation to science, due to their "gruesome" nature (Black, 2018). For some, decomposition research at an HTF may be perceived as undignified or disrespectful, but it is no less dignified than donation to a medical school for anatomy dissection.

Indeed, any HTF established in the UK would operate under the same ethical constraints as UK medical schools, with the enshrined principle of informed consent. Prospective donors to a HTF will be given as much information about the donation and research process as they require, and be given the opportunity to make informed choices about what they want to happen to their remains once on the HTF. As with donation to medical schools in the UK, the next of kin would have the right to veto the decision of the donor. Assuming a HTF in the UK was regulated by the Human Tissue Authority and with a recognised system of bequest by informed consent, there should be no objection by the public or scientific community on ethical grounds. Indeed, body donation programs at medical schools often have to decline offers of bequests as the donors are not suitable, due to amputations, tumours or other conditions, but a HTF would be able to accept donations from the majority of potential donors; meaning that donation to a HTF would allow more people to have their wishes granted after all. A growing number of people are keen to donate their bodies to forensic science and see it as a useful, beneficial alternative to burial or cremation that will directly help others after their death.

\section{The media and reputation}

The use of the term "body farm", and the media's insistent use of words such as 'gruesome', 'shocking' and 'horrifying' to describe the work undertaken at HTFs (Slater, 2017; Tingle, 2017) are not accurate or dignified ways to describe the scientific research undertaken at such facilities (Forbes, 2017), but their use does not seem to have hampered the reputation of HTFs amongst the public. The term 'body farm' was first used by Patricia Cornwell in a novel of the same name (Cornwell, 1994) to describe the Forensic Anthropology Center at the University of Tennessee, Knoxville, but since then has entered common parlance. The moniker has been embraced by the UTK HTF, and been adopted for a series of popular crime novels co-authored by the UTK HTF Directors, Bill Bass and Jon Jefferson (Bass and Jefferson, 2004; Bass, 2013). In the UK, a popular TV crime drama called 'The Body Farm', based around a fictional UK HTF (www.bbc.co.uk/programmes/b014sp3c), was commissioned and broadcast in 2011. If anything, the concept of outdoor laboratories where cadavers are placed to rot naturally seems to have captured the public's imagination, causing a flurry of offers of donation to HTFs (Oriti, 2017). Indeed, in the UK, where a HTF does not exist yet, relevant academics are being approached by members of the public offering to donate their bodies as soon as such a facility opens. Without a HTF in the UK currently, it is not possible to grant their dying wishes. The experience of Professor Shari Forbes, Director of AFTER, has been of no negative feedback from the public (Schubert, 2018), and this has been echoed in the UK and the Netherlands (Oostra, 2018). Of course, it is of paramount importance that the important research carried out by HTFs does not pander to the media or become 'edutainment' (Blau, 2017). Academics, practitioners and students involved in 
research or training at such facilities must always be mindful and respectful of the generous bequests made by the donors and their families, particularly when their work comes under scrutiny by the public.

\section{Conclusions}

The establishment of a Human Taphonomy Facility in the UK is understandably controversial. However, the increase in the number of facilities being funded and opening since 2012 is testament to their perceived value (Blau, 2017). Gill (2017) says that "the number of these research facilities will continue to grow as long as they provide useful research and educational opportunities, local communities accept them, and there are willing subjects (with informed consent) who agree to donate their bodies for this endeavour".

Ever increasing demands for expert evidence means that forensic scientists need to continually test, validate and increase research. It is dangerous to assume that results and experience gained from animal experiments can be applied to human bodies. The fact that differences in the decomposition process between human and pigs have been found (Connor et al., 2017, Dautartas et al., 2018, Knobel et al., 2018), should worry all forensic scientists, and indeed all those working in the criminal justice sector. These findings can only come from institutions that have the ability to compare human and animal decomposition, but is it important that further research occurs on this topic.

This is not to say that animal experiments should stop. Such work is important to develop ideas and to identify trends in taphonomy (Connor et al., 2017), and are invaluable for undergraduate projects. However, it is vital that students wishing to pursue a career in forensic science are exposed to the sensory experiences of human decomposition, something that can only be achieved at a HTF. Animal models do allow for some control over variables (size, weight, diet, etc.) but do not allow for data collection from subjects with known diseases, or exposure to medications or various medical treatments (Madea and Doberentz, 2017).

It is also vital to remember that there are many more areas of research relevant to criminal investigation other than the estimation of post-mortem interval. The creation of a HTF in the UK would mean that scientists could study many of the events and processes that fall under the term 'taphonomy': including search and location of human remains; identification of decomposed remains; persistence of DNA, fingerprints and trace evidence in association with decomposing human remains; interactions between cadavers and soil, water and ecology. HTFs are also of immense value to practitioner training and education (Williams et al., 2017). Furthermore, osteometric data and scans can be collected from donors (with informed consent), after decomposition studies have concluded, which would increase the relevance, accuracy and reliability of reference data in UK forensic anthropology research, which at present mostly relies on archaeological population studies (Mays, 2010).

The time is right for the establishment of a HTF in the UK. The public appetite for the creation of a HTF in the UK has never been greater. The existence of HTFs since 1981 and the rapid creation of eight more facilities since 2005 have led to a wealth of experience that can be shared between Directors (Bytheway et al., 2015) in order to develop protocols in compliance with UK regulations. It is expected that body donation to a UK HTF would be 
carried out the same way as current body donation to medical and anatomy schools, with informed consent, and the possibility of the next of kin to veto the donor's decision. This should mitigate any concerns about unethical practices. It is expected that the Human Tissue Authority would oversee and regulate the donation and human tissue research within a UK HTF. Directors of HTFs, whether in the UK or abroad, can agree on the ethical standards of respect, beneficence, justice, autonomy and dignity, to guide their creation of policies and best practices (Bytheway et al., 2015), in order to strike the right balance between providing an educational and research facility which aids Society in the pursuit of truth and justice, and protecting and respecting the rights of the donors, donor families, and users of the facilities.

\section{References}

Alapo, L. (2016) Humans-Pigs-Rabbits Decomposition Study to Impact Court Cases Worldwide. Tennessee Today. [Online]. Available at: https://news.utk.edu/2016/04/27/humanspigsrabbits-decomposition-study-impact-courtcases-worldwide/ [Accessed 12th July 2017].

Bachmann, J. and Simmons, T. (2010) The influence of pre-burial insect access on the decomposition rate. Journal of Forensic Sciences, 55, 893-900.

Bass, J. (2013) The Bone Thief: A Body Farm Novel. Harper, USA.

Bass, W. and Jefferson, J. (2004) Death's Acre: Inside the legendary 'Body Farm'. Sphere, USA.

Black, S. (2017). Body farms. Forensic Science, Medicine and Pathology, 1-2. DOI: $10.1007 / \mathrm{s} 12024-017-9917-\mathrm{y}$

Black, S. (2018) All that remains: A life in death. Transworld Publisher, London.

Blau, S. (2017) Body farms. Forensic Science, Medicine and Pathology, 13: 484-486. DOI: 10.1007/s12024-017-9922-1.

Buffington, S.A., Di Prisco, G.V., Auchtung, T.A., Ajami, N.J., Petrosino, J.F, CostaMattioli, M. (2016) Microbial Reconstitution Reverses Maternal Diet-Induced Social and Synaptic Deficits in Offspring. Cell, 165(7): 1762-1775.

Byard, R. W. (2017) Body farms - characteristics and contributions. Forensic Science, Medicine and Pathology, 1-2. DOI: 10.1007/s12024-017-9912-3.

Bytheway, J. Connor, M. Dabbs, G.R. Johnston, C.A. and Sunkel, M. (2015) The ethics and best practices of Human Decomposition Facilities in the United States. Forensic Science Policy and Management, 6(3-4): 59-68.

Cablk, M.E. Szelagowski, E.E. and Sagabiel, J. (2012) Characterization of the volatile organic compounds present in the headspace of decomposing animal remains, and compared with human remains. Forensic Science International, 220(1-3): 118-125.

Connor, M. Baigent, C. and Hansen, E. (2017) Testing of pigs as Human Proxies in Decomposition Studies. Journal of Forensic Sciences, 0(0) DOI: 10.1111/15564029.13727. 
Cornwell, P. (1994) The Body Farm. Berkley Publishing Group, New York, USA.

Cross, P. and Williams, A. (2017) Taphonomy Facilities as Teaching Aids. In: Williams, A. Cassella, J.P. and Maskell, P.D. (Eds.) (2017) Forensic Science Education and Training. Wiley, UK.

Crown Prosecution Service (2015) Expert evidence - legal guidance. [Online] Available at: https://www.cps.gov.uk/legal-guidance/expert-evidence [Accessed 7th August 2018].

Dautartas, A., Kenyhercz, M.W., Vidoli, G., Meadows Jantz, L., Mundorff, A., and Steadman, D.W. (2018) Differential Decomposition among Pig, Rabbit and Human Remains. Journal of Forensic Sciences, 0(0) DOI: 10.111/1556-4029.13784.

Enserink, M. (2017) Amsterdam to host Europe's first 'forensic cemetery'. Science Magazine. [Online]. Available at: http://www.sciencemag.org/news/2017/01/amsterdam-hosteuropes-first-forensic-cemetery [Accessed 12 ${ }^{\text {th }}$ July 2017].

Forbes, S. (2017) Body farms. Forensic Science, Medicine and Pathology, 1-2. DOI: 10.1007/s12024-017-9924-z.

Forensic Science Regulator (2018) Legal obligations issue 6. [Online] Available at: https://www.gov.uk/government/publications/legal-obligations-issue-6 [Accessed 7th August 2018].

Gill, J. (2017) Body farms. Forensic Science, Medicine and Pathology, 1-2. DOI: 10.1007/s12024-017-9919-9.

Green, A.; Fleeman, M. (2016) Casey Anthony Trial: 'Body Farm' Expert Testifies. People. [Online]. Available at: http://people.com/crime/caylee-anthony-murder-experttestifies-about-air-samples/ [Accessed 25 ${ }^{\text {th }}$ July 2017].

Hrala, J. (2016) Human 'body farm' reveals we need to stop using pigs to establish time of death. Science Alert. [Online]. Available at: http://www.sciencealert.com/pigs-may-notbe-the-most-amazing-forensic-tool-after-all-finds-body-farm-researchers [Accessed $2^{\text {nd }}$ July 2016].

Hyde, E.R., Haarmann, D.P., Lynne, A.M., Bucheli, S.R. and Petrosino, J.F. (2013) The Living Dead: Bacterial Community Structure of a Cadaver at the Onset and End of the Bloat Stage of Decomposition. PLOS ONE, 8(10): e77733. https://doi.org/10.1371/journal.pone.0077733

Irish, L. (2018) The use of Human Taphonomy Facilities for victim recovery dog training. Public symposium 'Does the UK need a 'Body Farm'?', University of Wolverhampton, $13^{\text {th }}$ June 2018.

Janaway, R., Percival, S. and Wilson, A. (2009) Decomposition of Human Remains. In: Percival S, Microbiology and Aging. Humana Press. pp. 313-334.

Knobel, Z., Ueland, M., Nizio, K.D., Patel, D. and Forbes, S. L. (2018) A comparison of human and pig decomposition rates and odour profiles in an Australian environment. Australian Journal of Forensic Sciences. DOI: $10.1080 / 00450618.2018 .1439100$ 
Kuzminsky, S. C. and Gardiner, M. S. (2012) Three-dimensional laser scanning: potential uses for museum conservation and scientific research. Journal of Archaeological Science, 39 (8): 2744-2751.

Luong, S., Forbes, S.L., Wallman, J.F. and Roberts, R.G. (2018) Monitoring the extent of vertical and lateral movement of human decomposition products through sediment using cholesterol as a biomarker. Forensic Science International, 285: 93-104.

Lynch-Aird, J., Moffatt, C. and Simmons, T. (2015) Decomposition rate and pattern in hanging pigs. Journal of Forensic Sciences, 60, 1155-1163.

Madea, B. and Doberentz, E. (2017) Body farms. Forensic Science, Medicine and Pathology. DOI: $10.1007 / \mathrm{s} 12024-017-9918-\mathrm{x}$

Mays, S. (2010) Human osteoarchaeology in the UK 2001-2007: A bibliometric perspective. International Journal of Osteoarchaeology, 20: 192-204. DOI: 10.1002/oa.1021

Oostra, R-J. (2018) Personal communication. ARISTA, Amsterdam.

Oriti, T. (2017) Forensic scientists overwhelmed by number of donors to NSW body farm. $A B C$ News. 12 May. [Online] Available at: http://www.abc.net.au/news/2017-0512/forensic-scientists-at-body-farm-overwhelmed-by-number-of-donors/8520058 [Accessed $1^{\text {st }}$ February 2018].

Pechal, J., Crippen, T., Benbow, M.E., Tarone, A., Dowd, S., et al. (2013) The potential use of bacterial community succession in forensics as described by high throughput metagenomic sequencing. International Journal of Legal Medicine, 1-13.

President's Council of Advisors on Science and Technology (2016) Forensic science in criminal courts: Ensuring scientific validity of feature comparison methods. [Online] Available https://obamawhitehouse.archives.gov/sites/default/files/microsites/ostp/PCAST/pcast forensic_science_report_final.pdf [Accessed $9^{\text {th }}$ August 2018].

Pringle, J.K., Jervis, J.R., Roberts, D., Dick, H.C., Wisniewski, K.D., Cassidy, N.J. \& Cassella, J.P. (2016) Geophysical monitoring of simulated clandestine graves using electrical and ground penetrating radar methods: 4-6 years. Journal of Forensic Sciences, 61, 309-321.

Pringle, J.K., Jervis, J.R., Hansen, J.D., Cassidy, N.J., Jones, G.M \& Cassella, J.P. (2012) Geophysical monitoring of simulated clandestine graves using electrical and Ground Penetrating Radar methods: 0-3 years. Journal of Forensic Sciences, 57, 1467-1486.

Schultz, J.J., Collins, M.E., Falsetti, A.B. (2006) Sequential monitoring of burials containing large pig cadavers using ground-penetrating radar. Journal of Forensic Sciences, 51, 607-616.

Schubert, M. (2018) Life or Death Research? The Pathologist, June 2018. [Online] Available at: https://thepathologist.com/issues/0618/life-or-death-research/ [Accessed $8^{\text {th }}$ August 2018].

Schultz, J.J., (2008) Sequential monitoring of burials containing small pig cadavers using ground-penetrating radar. Journal of Forensic Sciences, 53, 279-287.

Shirley, N., Wilson, R. and Meadows-Jantz, L. (2011) Cadaver Use at the University of Tennessee's Anthropological Research Facility. Clinical Anatomy, 24: 372-380. 
Slater, A. (2017) Inside Australia's first body farm where rotting corpses and the thick, pungent smell of death fills the air. Mirror. 25 June 2017. [Online]. Available at: https://www.mirror.co.uk/news/uk-news/inside-australias-first-body-farm-10684440 [Accessed 10 ${ }^{\text {th }}$ May 2018].

Smialek, J. and Levine, B. (1998) Diabetes and Decomposition: A Case of Diabetic Ketoacidosis With Advanced Post-mortem Change. The American Journal of Forensic Medicine and Pathology, 19(1): 98-101.

Stadler, S., Stefanuto, P. Brokl, M. Forbes, S. and Focant, J. (2013) Characterization of volatile organic compounds from human analogue decomposition using thermal desorption coupled to comprehensive two-dimensional gas chromatography-time-offlight mass spectrometry. Analytical Chemistry. 85(2), 998-1005

Steele, K. (2017) Agreement reached on forensic research campus. The Laker/Lutz News, $4^{\text {th }}$ October, 2017. [Online]. Available at: http://lakerlutznews.com/lln/?p=50661 [Accessed $1^{\text {st }}$ June 2018].

Stokes, K., Forbes, S., Tibbett, M. (2013) Human vs Animal: Contrasting Decomposition Dynamics of Mammalian Analogues in Experimental Taphonomy. Journal of Forensic Sciences, 58: 583-591.

Stuzner, I. (2016) 'Body farm' proposed for central Queensland would be world first for tropics. $A B C$ News, $22^{\text {nd }}$ November 2016. [Online]. Available at: http://www.abc.net.au/news/2016-11-22/body-farm-proposed-for-central-queenslandwould-be-world-first/8047048 [Accessed $1^{\text {st }}$ June 2018].

Svoboda, E. (2009) The Truth, Revealed by Bugs: The Case of Brookey Lee West. New York Times. [Online]. Available at: http://www.nytimes.com/2009/05/12/science/12filefly.html [Accessed 12 ${ }^{\text {th }}$ July 2017].

Thornton, L. 2017. Operation Ben Needham turned to Texas Body Farm for help with clues found on Kos. The Mirror. [Online]. Available at: http://www.mirror.co.uk/news/uknews/operation-ben-needham-turned-texas-10858732 [Accessed $25^{\text {th }}$ July].

Tingle, R. (2017) Inside the body farm: Gruesome images show Texas institute where corpses are left to rot in cages as part of scientific research to help solve crimes. Daily Mail Online. 15 December 2017. [Online] Available at: http://www.dailymail.co.uk/news/article-5183149/Gruesome-images-inside-Texasbody-farm.html [Accessed 10 ${ }^{\text {th }}$ May 2018].

Troutman, L., Moffat, C. and Simmons, T. (2014) A preliminary examination of differential decomposition patterns in mass graves. Journal of Forensic Sciences, 59: 621-626

Vass A (2001) Beyond the Grave - Understanding Human Decomposition. Microbiology Today, 28: 190-192.

Wallman, J. F. (2017) Body farms. Forensic Science, Medicine and Pathology, 13:487-489. DOI: $10.1007 / \mathrm{s} 12024-017-9932-\mathrm{z}$

Williams, A., Cassella, J.P. and Pringle, J.K. (2019) The Ethical Considerations for Creating a Human Taphonomy Facility in the United Kingdom. In: Squires, K., Errickson, D. and Marquez-Grant, N. (Eds.) (2019) Ethical Challenges in the Analysis of Human Remains. Springer, UK. In press. 
Zhou, C. and Byard, R. (2011) Factors and processes causing accelerated decomposition in human cadavers - An overview. Forensic and Legal Medicine, 18(1): 6-9. 